\section{WATER AND ICE, TO-DAY AND IN THE} GLACIAL EPOCH.

MR. G. K. GILBERT'S survey of the Niagara Falls (see Nature, vol. 1xxv., p. 607) is not to stand alone. In the "Summary Report of the Geological Survey Departinent of C/had/ fpr 1905 " (Ottawa, 1906) Dr. J. W. Sponfer prom ises a Com account of the Niagara district, which he is/ag eeloly confident will reveal "discoveries of the greatest importance" (p. 9r). Soundings have been thacelin the gorge below the falls, in areas previously thtested, and wells have been sunk to prove the depth of an Interestirrg buried channel, filled with glacial drift.

In contrast with this region of attractive turmoil and erosion, Mr. T. W. Kingsmill takes us to the lower Hwangho, in China, where the river " is prevented by the laws of hydraulics from excavating its bed, and has in consequence to flow on the surface" "The Hydraulics of Great Riwers Flowing through Alluvial Plains," Shanghai, North China Herald Office, igo6). If once this great body of water effects a breach in one of its banks, it "shows no disposition, when the flood subsides, to return to its bed, but invariably finds some easier course to the sea." The Hwangho, according to Mr. Kingsmill's interesting historic sketch, broke its right bank in 1854 , and from that date to I 870 wandered over a wide stretch of country, depositing a layer of sand from 6 feet to 8 -feet thick. In Horan, not far from Mangtsin, 250 feet of river-alluvium, thoroughly pervious to the water above it, were passed through in sinking for a coal mine. Much of the drainage thus reaches the sea by underground channels, and the main river actually diminishes in volume below Mangtsin. The extensive deposits that are forming in the Gulf of Pechili, at the rate of 208,000 tons per day (p. 3i), increase the difficulty of controlling the river in the interior. We learn that fishermen on stilts may be met with out at sea miles before the low coast is sighted. Mr. Kingsmill's suggestions for correcting the stream are enlivened by the printing of a discussion of them by $\mathrm{Mr}$. Tyler. $\mathrm{Mr}$. Kingsmill proposes to continue banking up the river; Mr. Tyler would organise floods at selected points, and let the river build its huge conoidal plain under proper supervision. The silt would then be disposed of in an orderly manner, and the river-bed would cease to rise. The titanic struggle of man with the Colorado River (NATURE, vol. Ixxv., p. 501) suggests, however, that Mr. Tyler's dumping-grounds might at times get more water and less silt than they were prepared for.

There are many districts that have been assailed by diluvial flooding and deposition in comparatively recent times, where now desiccation has set in, with the accompaniment of the formation of löss and sand-dunes. The extremely uncomfortable conditions that prevailed in Furope at the close of Glacial times are shown by Prof. Steinmann to have been paralleled in South America ("Uber Diluvium in Süd-Amerika," Monatsberichte d. deutschen geol. Gesell., 1906). The author believes that the vast extent of fluvio-glacial deposits, which have filled up the hollows of the Cordillera and spread so freely jver Patagonia, can only be accounted for by a series of glacial epochs. He sees, moreover, in the level expanses of calcareous mud round the salt-lakes of Bolivia and Argentina the evidences of former fresh-water lakes, in which Bythinia flourished. "The traces of the last iceage may be followed across the equator as far as Cape Horn." The climatic differences that prevail at the present day are now shown to have existed, both in Europe and South America, during the melting of the last icesheets; and "hence we shall do well to discard all attempts at explaining glacial epochs that are not of a universal character:'

In a paper furnished with an abstract in French ("Till Frågan om Ost-Finmarkens Glaciation .och Nivăförändringar," Bull. Comm. géol. de Finlande, No. 18, 1907), Herr V. Tanner describes the course of the ice in Finmark in glacial times as being from S.W. to N.E., and traces the variations in the sea-level by observations on terraces cut in the rock and on gravelly raised beaches. While the ice was melting from the land, the continental mass was rising, and thus. offered a more and more extended front to the action of the waves.

While the terminal tongues of glaciers in Alberta and British Columbia have not in all cases shown a marked retreat in recent years, Messrs. George and W. S. Vaux prove that the ice-masses have become greatly reduced (Proc. Acad. Nat. Sci. Philadelphia, December, Igo6, p. 568): The Illecillewaet Glacier has withdrawn about 250 feet in eight years; but its annual rate of recession is becoming slower, and its rate of flow is now actually greater than in 1899. Conical moraines appearing through the ice on the Wenkchemna Glacier (p. 577) are 
fluence the ice-front; but the author points out that the crushing of the resisting masses in the lowlands is just what might be expected from a sudden addition of snow to the reservoirs in the hills. Changes of level, moreover, amounting to as much as 47 feet, took place in Alaska in 1899 , and these may in part account for local variations. The description of the broad alluvial fan of the Hayden Glacier, with its streams changing in position and depth from day to day, is impressively interesting, as an illus tration of the rate at which our own " glacial gravels" may have been distributed.

Perhaps Prof. Tarr's remarkable but modest paper will be hailed by $M$. Edouard Piette as an argument in favour of his more startling views " Déplacement des Glaces polaires et grandes Lxtensions des Glaciers," Saint Quentin, 1906, pp. 36). M. Piette attributes the glacial climate of the northern hemisphere to the release of iccmasses by earthquakes at the pole. He urges that this would be assisted by the uprush of volcanic vapours and hot springs along the fissures, while cataclysms like that of the Straits of Sunda would fling the ocean waters irresistibly against the polar ice-cap. The Atlantic continent from Ireland to Iceland fell in about the same time by an "affaissement définitif," and the whole ice sped southward, leaving the pole for a time free. We confess that we can read M. Piette's paper far more sympathetically, now that we have the advantage of Prof. Farr's conclusions; but there is a whirl of death and horror about his description of the great catastrophe that reminds us of the old diluvial theories, to say nothing of Dante's second circle. We read, moreover; that icebergs nowadays (p. 6), running aground on the coast. "d'Irlande ou d'Ecosse, y déterminent des froids intenses, capables de geler la végétation." Such a phenomenon would attract thousands of excursionists, and would surely be mentioned in our veracious daily papers.

The erosive power of glaciers is clear, wherever joints or any other planes of division in a rock are so arranged as to slope up against the direction of movement of the ice. "Plucking," then becomes a feature of the district. But, even on ice-smoothed surfaces, signs of rock-fracturn under the pressure of the glacier are occasionally found. Prof. G. K. Gilbert discusses these " crescentic gouges." (Bull. Geol. Soc. America, vol. xvii., I906, p. 303) as due to the presence of subglacial boulders. A line of type omitted on p. $3^{1} 3$ renders one of the sentences obscure; but the argument put forward is that ice must have "greater power of resistance [to flowage] than some students have been disposed to admit. . . . The more rapid the flow the stronger the resistance. Therefore the crescentic gouges... may testify also to the relative rapidity of glacier movement." Prof. Gilbert's photooraphic illustrations are excellent, as are those of subrlacial potholes in a subsequent paper on moulin work (ibid., p. 317), in which it is pointed out that such moulin-hollows may be bounded during their formation on one side by rock and on another by the ice, leaving a rocksurface with flexuous incurvings when the glacier has disxppeared by melting.

Prof. R. S. Tarr "Glacial Erosion in Alaska," Popular Science Monthly, vol. lxx., roo7, p. 99) discusses the broader features of glacial erosion as displayed in hanging valleys. He postulates, in common with other writers. a considerable deepening of the main valley by ice; but may we not presume that the lateral valleys were largely developed and cut back by the frost-nibbling, under glacial conditions, on which Profs. Penck and Davis lay such proper stress? A main valley, with feeble lateral tributaries, may be occupied up to a certain level by ice, which widens it, deepens it somewhat, and wears back the poorly developed projecting spurs. The lateral valleys are at the same time rapidly weathered back under the now and more strenuous conditions of high-level erosion, and rockv cirques are formed at their heads in place of confluent stream-grooves. Tributary ice gathers in cach lateral hollow, and the erosion above it, and also below it whre a rushing stream emerges on the crevassed main glacier, cannot operate below the level where the two masses unite: and finally, if melting is rapid, hanging valleys are left, which will in time be cut down bv ordinarv weathering to the level of the main No. I981, vคr.. 767 valley-floor. If the main glacier diminishes by ablation slowly, the tributary glaciers and their subglacial streams cut down their valleys to keep pace with the falling surface, and these valleys finally cease to be of the hanging type, though showing glaciated floors. This seems to have been the case in much of central Connemara. This is not the place, however, to attempt to modify the theory of the deepening of glacial valleys so brilliantly put forward by Prof. W. M. Davis. Suftice it that Prof. Tarr disposes successfully of several of the fantastic theories put forward to account for a phenomenon of very wide occurrence in glaciated areas.

In the Verhandlungen der schweizerischen naturforschenden Gesellschaft, St. Gallen meeting, 1906, pp. 26x-307, Herr J. Früh, of Zürich, writes a general essay, "Ueber Form und Grösse der glazialen Erosion," illustrated by personal observations on the topography of Switzerland. Hanging valleys, Alpine lakes, and "Uebertiefungen " are discussed, and useful references are given to Davis, Penck, and Brückner.

Lastly, we must not forget the work of water in its immense circulatory systems below the surface. The investigation of the "Underground Water Resources of Alabama," by Mr. E. Allen Smith (Geological Survey of Alabama, Montgomery, Alabama, x907), has provided us with a neatly bound volume which is in many ways a guide to the geology of the State. The conditions favouring underground flow and the emergence of springs are discussed in pp. 32 to 63 in a manner that will interest engineers in general, as well as the ordinary citizen between the Tennessee River and the Gulf of Mexico. The great region for artesian water-supply in Alabama lies along the band of Cretaceous limestone, the Selwa Chalk, which passes just south of Montgomery. Several medicinal springs occur among the Tertiary strata towards the Gulf, including one (p. 320) that has been said to give protection against malarial fever.

G. A. J. C.

\section{ENDOWMENTS FOR SECONDARY EDUCATION.}

WHILE writing this article the following questions have been in mind :-(i) What are the nury $\mathrm{r}$ and extent of the educational endowments of our fogt public and other endowed schools $N$ (2) What we the intentions of their foundes?
sent realiged? Hoy forsuch intentions at pregenerally a ailate se as to increase their benefit to the public with the minimum departure from those intentions?

The anfwer to the two latter questions must be that it is largely a question of degree; from the nature of the case an expression of opinion, not a precise estimate, is all that can be attempted. The first two questions relate to definite matters of fact, the answers to which ought to be ascertainable, but are only approximately to be determined. $\Lambda$ better reply to (I) would be forthcoming had either the late or the present Government fulfilled their promises to obtain a return, to be presented to the House of Commons, giving statistics of the finance of all endowed schools. We are informed that the Charitable Trusts Division of the Board of Education is considering the details to be sought in such inquiry, and it is to be hoped that considerations of its cost will no longer be allowed to stay its fulfilment. In the meantime, the following condensed account, based on such materials as were obtainable, is submitted as calculated to correct some of the grosser errors prevalent with regard to the subject of our ancient endowments. The writer wishes to acknowledge his indebtedness to the writings of $\mathrm{Mr}$. A. F. Leach (Charity Commissioner) and to the courteous help of the officials at the Education Board, of course without implying that they have any responsibility for the statements which follow.

\section{Endowed Schools before the Reformation.}

The records included in Mr. A. F. Leach's book entitled "English Schools at the Reformation" (Constable) show that 200 grammar schools at least, and more probably 